\title{
THE INFLUENCE OF THE CHANGES IN WIND VELOCITY ON THE OUTER HEAT EXCHANGE OF THE BUILDINGS
}

\author{
${ }^{1}$ Tarasevych D.V., Ph.D., Associate Professor, \\ dasha_tar@ukr.net, ORCID: 0000-0002-1153-7669 \\ ${ }^{1}$ Bogdan O. V., Assistant, \\ ovbogdan@gmail.com, ORCID: 0000-0003-1610-5598 \\ ${ }^{1}$ Odessa State Academy of Civil Engineering and Architecture \\ 4, Didrikhson Str., Odessa, 65029, Ukraine
}

\begin{abstract}
When choosing architectural and planning solutions, such climatic factors as air temperature and humidity, having scalar quantities, as well as solar radiation, wind and precipitation having vector characteristics, must be taken into account. The calculated climatic parameters for the design of building enclosing structures, heat loss calculations and heat supply regulation are provided in the current documentation on norms and standards. The practical exploitation of various buildings demonstrates that in terms of initial climatic data, the choice of design parameters is not always efficiently justified; hence, the influence of the environment on the heating regime of the structures is insufficient in the estimations and sometimes erroneous. The wind is one of such climatic parameters. Its velocity and repeatability impact the heat exchange of the building structure with the environment as well as the alteration in temperature regime. The wind current towards the building creates additional pressure on the facade of the construction from the wind side direction. This leads, firstly, to air infiltration via the enclosing structures, and secondly, to the rise of heat exchange from the outer surface of the wall on the windward side.

Based on estimated and analytical research, the values of the change in wind velocity depending on the altitude were analyzed, and its influence on the heat loss during heating of multistorey buildings was assessed. The alterations in the wind velocity depending on the altitude were analyzed in the conditions of dense (urban) and broad construction. Besides, the authors presented the dependence of the convective component of the heat transfer coefficient of the outer surface of the structure on the values of the wind velocity. Based on the performed and presented calculations, it can be noticed that the heat transfer of the external structure will be much higher for multi-storey buildings than for mid-rise constructions. Thus, the convective component of the heat transfer coefficient of the outer surface rises by $36 \%$ when the wind velocity increases from $5 \mathrm{~m} / \mathrm{s}$ to $7 \mathrm{~m} / \mathrm{s}$. If not taking into consideration this dependence in the design, it can significantly influence the estimation of heat loss and energy efficiency of buildings, especially when it is about the increased percentage of facades glazing.

The authors of the article assessed the heat loss for heating the windward and leeward facades at average values of the outside air temperature during the heating season in Ukraine. Hence, for constructions higher than $70 \mathrm{~m}$ with a calculated wind velocity of $5 \mathrm{~m} / \mathrm{s}$, heat losses increase from $10 \%$ to $19 \%$. Such great difference in heat loss between the windward and leeward walls of the building requires increased thermal protection from the prevailing winter winds. Therefore, when designing multi-storey buildings, it is necessary to take into account changes in wind velocity according to the altitude.
\end{abstract}

The obtained results can be useful both for choosing architectural and planning solutions, like the materials for external enclosing structures and for the objective assessment of the wind protection degree of individual buildings and territories.

Keywords: wind velocity, energy-efficiency, heat exchange coefficient, heating regime, enclosing structures, windward facade, leeward facade.

Introduction. Such climatic factors as temperature and humidity have scalar characteristics, while solar radiation, wind and precipitation are vector characteristics. This must be taken into

Bulletin of Odessa State Academy of Civil Engineering and Architecture, 2021, no. 83, page 148-155 
account when choosing architectural and planning solutions for building and structural solutions of constructions. The current regulatory documentation provides the calculated climatic parameters for the design of building enclosing structures, heat loss calculations, heat supply regulation, etc. The practical exploitation of various buildings and structures shows that the choice of design parameters in most cases is not sufficiently justified in terms of initial climatic data and therefore, the impact of the environment on the heating regime of the building is insufficient in the calculations.

Analysis of recent research and publications. The energy efficiency of buildings significantly depends on the proper consideration of various climatic parameters in the design and construction of modern buildings. For most cities in Ukraine, the values of these parameters are provided in DSTU-N B V.1.1-27:2010 "Protection from dangerous geological processes, harmful opretional impact, from fire. "Budivelna klimatolohiia". K.: Minregionbud Ukraïni, 2011 [1]. This regulative document specifies the characteristics of wind direction, its repeatability and velocity, which affect the choice of planning decisions of the building area, architectural and structural solutions of buildings and the calculation of aerodynamic impact on the construction and the territory. Nowadays, many works are devoted to the estimation of the aerodynamic impact of wind on buildings [2-4]; however, the velocity and repeatability of wind also affect the heat exchange of the building structure with the environment [5-7], the change in temperature regime and thus, the energy efficiency of the buildings. The wind flow towards the building creates additional pressure on the facade of the house from the wind side direction $[4,6,7]$, which leads to air infiltration through the enclosing structures, that's why it is extremely important to assess the impact of wind on the heat loss of buildings. Such an assessment of the impact of wind velocity on the heat loss of five- and sixteen-storey buildings is presented in studies $[8,9]$ but today there is an important issue to assess the impact of wind on the heat loss of multi-storey buildings over $73.5 \mathrm{~m}$ high because, as it is well-known, both temperature and wind velocity vary at the altitude from the earth surface. DBN V.2.2-41:2019 "High-rise buildings". K.: Minrehionbud Ukrainy, 2019 [10], article 13.3, states that "for the enclosing structures located above the conventional height of the building of 73.5 $\mathrm{m}$, the estimated value of the outside air temperature is taken $1^{\circ} \mathrm{C}$ lower for every $50 \mathrm{~m}$ of building height relative to the estimated values", but has no recommendations to take into account the changes in the wind velocity.

It must be noted that the methodology of the estimation of the heat loss of the heated premises, including ventilated is presented in EN 12831-1:2017 "Energy performance of buildings. Method for calculation of the design heat load. Part 1: Space heating load, Module M3-3" [11]. The heat loss of the infiltration air is estimated considering the compensation factor for the altitude of the premises which includes the increase in the wind burden. However, the impact of changes in wind velocity on the heat exchange of the outer surface of the building is not taken into consideration. This can lead to a greater heat loss of high-rise buildings and reduce their energy efficiency. Therefore, a differentiated approach is needed to create comfortable microclimate conditions.

Tasks and objectives of the work. The purpose of this article is to determine the change in wind velocity according to the altitude and the significance of wind influence on heat consumption of high-rise buildings using functional calculations. The results of these studies can be useful in the choice of architectural and planning decisions, the type of materials of the external enclosing structure, as well as for an objective assessment of the degree of wind protection of individual buildings and areas.

Materials and methods of research. The current regulatory documentation of Ukraine, existing methods of calculation and assessment of wind velocity at the altitude from the earth surface, scientific publications and meteorological data for different cities of Ukraine have been used in this study.

Results of research. To estimate the change in wind velocity by altitude, exponential function is usually used $[4,12,13]$ : 


$$
v_{H}=v_{0}\left(\frac{H}{10}\right)^{n}
$$

where $v_{H}$ - wind velocity at a certain altitude $H$;

$v_{0}-$ wind velocity at the altitude of $10 \mathrm{~m}$;

$n$ - exponent.

In formula (1), the exponent $n$ can have different values depending on the geographical location, the type of the terrain, building density and wind velocity $v_{0}$ [13]. Thus, some authors [4, 14] recommend taking the value of the exponent of 0.33 for the centres of large cities. A detailed study of the dependence of this parameter on the season and time of day is given in the study [12] based on meteorological observations at the Askania-Nova station (Ukraine) and gives the average annual value: $n=0.24$. Analyzing the results of studies by various authors, it can be noted that for dense construction of buildings higher than $25 \mathrm{~m}$ it is reasonable to use $n=0.33$ and for sparse construction of buildings with an average height of $10 \mathrm{~m}$ this figure should be equal to 0.24 .

In order to compare the change in wind velocity according to the altitude in dense and loose construction, the estimated values of wind velocity for two different indicators of degree $n-0.24$ and 0.33 are presented in Fig. 1. According to the above-mentioned dependence, it can be seen that at the thirty-storey building altitude the wind velocity increases approximately one and a half times in the case of loose construction $(n=0.24)$ and almost twice in the case of dense construction $(n=0.33)$.

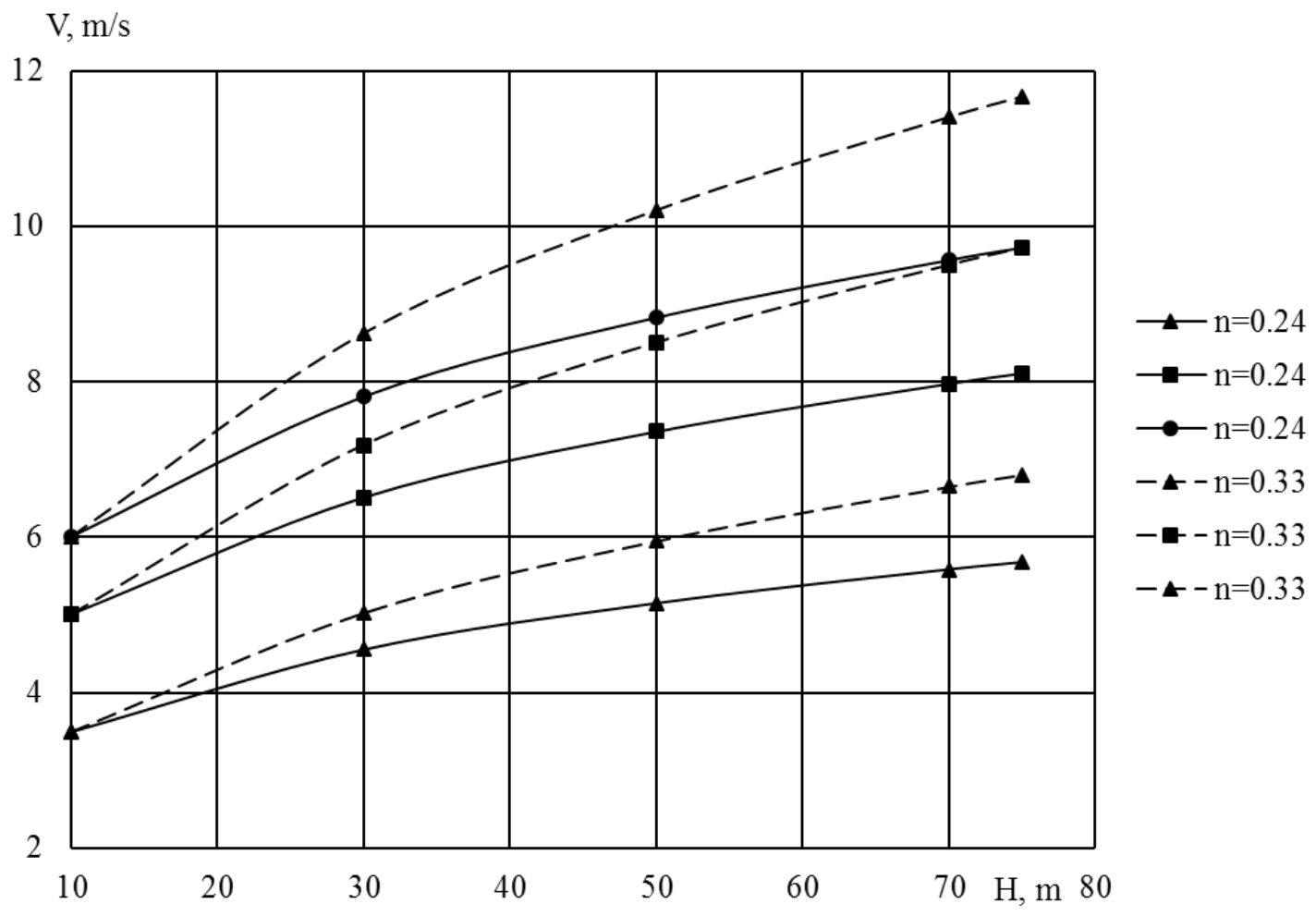

Fig. 1. Dependences of wind velocity on height at different values of $n$ parameter

There is a question of the assessment of a difference of heat losses of buildings taking into account an increase in wind velocity according to altitude. Thus, when estimating the heat exchange resistance of the enclosing structure, the value of the heat exchange coefficient of the outer surface of the structure is used [14]. This coefficient depends on the conditions of convective heat exchange and heat radiation, and can be presented as the sum of two corresponding terms:

$$
\alpha_{o}=\alpha_{c}+\alpha_{r},
$$

$\alpha_{c}$ - heat transfer coefficient by convection; 
$\alpha_{r}$ - heat transfer coefficient by radiation.

According to Frank's formula [5], the convective component of the heat transfer coefficient of the outer surface of the enclosing structure depends on the value of the wind velocity $(v)$ :

$$
\alpha_{c}=7.34 \cdot v^{0.656}+3.78 e^{-1.91 \cdot v} .
$$

This dependence is demonstrated in Fig. 2 for the estimated values of wind velocity $v=5,8,10,12 \mathrm{~m} / \mathrm{s}$.

Based on the conducted and presented in Fig. 2 estimations, it can be noted that the heat exchange coefficient at a wind velocity of $12 \mathrm{~m} / \mathrm{s}$ is more than $70 \%$ different from the heat exchange coefficient at a wind velocity of $5 \mathrm{~m} / \mathrm{s}$, that is, for high-rise buildings, heat exchange of the external structures will be much higher than for medium-rise buildings. If this dependence is not taken into account in the design, it can significantly affect the estimation of the heating condition of the premises, especially when it is about an increased percentage of glazing (more than $18 \%$ for residential buildings and more than $25 \%$ for public ones [16] on exterior facades [17]). Thus, the heat exchange of external enclosing structures $30 \mathrm{~m}$ high increases.

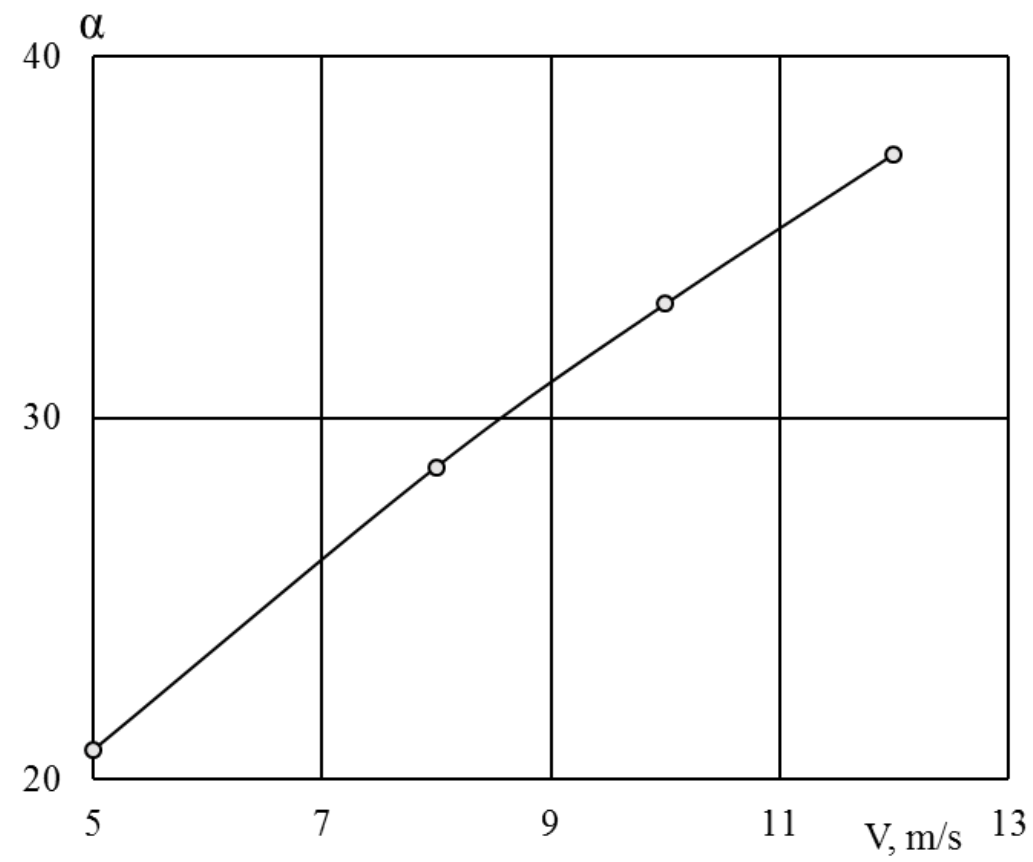

Fig. 2. The dependence of the convective component of the heat exchange coefficient of the outer surface on the wind velocity

To estimate heat consumption for windward and leeward facades heating, the following empirical dependencies can be used [9]:

$$
Q_{o v i}^{w}=\frac{1}{2}\left[\left(Q_{e}+Q_{h}\right) \cdot \frac{t_{p}-t_{o i}}{t_{p}-t_{o e}} \cdot\left(a+(1-a)\left(\frac{v_{i}}{v_{e}}\right)^{2}\right)-Q_{h}\right],
$$

where $Q_{o v i}^{w}$ - heat consumption of the windward facade at current figures of outdoor air temperature $t_{o i}$ and wind velocity $v_{i}$;

$Q_{e}$ - estimated heat consumption at the calculated figures of outdoor air temperature $t_{o e}$ and wind velocity $v_{e}$;

$Q_{h}$ - household heat emissions;

$t_{p}$ - air temperature on the premises; 
$a$ - coefficient which value depends on the estimated value of wind velocity: $a=0.94$ if $v_{e}=2 \mathrm{~m} / \mathrm{s} ; a=0.8$ if $v_{e}=5 \mathrm{~m} / \mathrm{s}$ and $a=0.51$ if $v_{e}=10 \mathrm{~m} / \mathrm{s}$.

Heat consumption for a windward facade is determined by the following formula:

$$
Q_{o v i}^{l}=\frac{1}{2}\left[\left(Q_{e}+Q_{h}\right) \cdot \frac{t_{p}-t_{o i}}{t_{p}-t_{o i}} \cdot a-Q_{h}\right] .
$$

Therefore, the difference between the cost of heating windward and leeward facades can be found the following way:

$$
\Delta Q=Q_{o v i}^{w}-Q_{o v i}^{l}=\frac{1}{2}\left[\left(Q_{e}+Q_{h}\right) \cdot \frac{t_{p}-t_{o i}}{t_{p}-t_{o e}} \cdot(1-a) \cdot\left(\frac{v_{i}}{v_{e}}\right)^{2}\right]
$$

The average figures of the outside air temperature in the heating season across Ukraine [1]:

$$
\frac{t_{p}-t_{o i}}{t_{p}-t_{o e}}=0.8
$$

so, if $a=0.8, v_{i}=v_{e}=5 \mathrm{~m} / \mathrm{s}$ and

$$
\frac{Q_{h}}{Q_{e}}=0.2
$$

the ratio of the difference between the costs of heating windward and leeward facades to the estimated heat costs are:

$$
\frac{\Delta Q}{Q_{e}}=9.6 \%
$$

If to take into consideration that for buildings over $70 \mathrm{~m}$ high the wind value on the middle floors is $v_{i} \approx 7 \mathrm{~m} / \mathrm{s}$ at the estimated wind velocity $v_{e}=5 \mathrm{~m} / \mathrm{s}$, this ratio $\Delta Q / Q_{e}$ has the value of almost $19 \%$.

Such a big difference in heat consumption between the windward and leeward walls of the building requires increased thermal protection of the walls from the dangerous (frequency of wind $P \geq 12,5 \%$ and $v \geq 4 \mathrm{~m} / \mathrm{c}$ ) winter winds, especially for high-rise buildings.

Conclusion and prospects for further research. In this study, the change in wind velocity according to the altitude in the conditions of the dense and loose construction has been investigated. The presented results indicate a significant increase in wind velocity in dense construction: if at the altitude of $10 \mathrm{~m}$ the wind velocity is $5 \mathrm{~m} / \mathrm{s}$, it will be $7.1 \mathrm{~m} / \mathrm{s}$ at the altitude of $30 \mathrm{~m}$ and $9.7 \mathrm{~m} / \mathrm{s}$ at the altitude of $70 \mathrm{~m}$. This, in turn, leads to an increase in heat exchange from the outer surface of the wall on the windward side. Thus, the convective component of the heat exchange coefficient of the outer surface increases by $36 \%$ when the wind velocity changes from $5 \mathrm{~m} / \mathrm{s}$ to $8 \mathrm{~m} / \mathrm{s}$. The difference in heat consumption for heating the building from the windward and leeward sides concerning the calculated allows saying that with increasing height of the building heat loss increases as well. Therefore, given that there are standards for energy efficiency in Ukraine, these estimations can be useful in the design and construction of multi-storey buildings.

\section{References}

[1] DSTU-N B V.1.1-27:2010. Zakhyst vid nebezpechnykh heolohichnykh protsesiv, shkidlyvykh ekspluatatsiinykh vplyviv, vid pozhezhi. Budivelna klimatolohiia. K.: Minregionbud Ukraïni, 2011.

[2] A.V. Airapetov, V.V. Vyshinsky, A.V. Katunin, "Numerical and experimental research of hight-rise buildings and structures aerodynamics in the presence of environmental building", Trudy MFTI, vol. 9, no. 2, pp. 5-12, 2017. 
[3] M.K. Mihaylova, V.S. Dalinchuk, A.V. Bushmanova, L.V. Dobrogorskaya, "Proektirovanie, stroitelstvo i ekspluatatsiya vyisotnyih zdaniy s uchetom aerodinamicheskih aspektov", Stroitelstvo unikalnyih zdaniy $i$ sooruzheniy, Issue 10 (49), pp. 59-74, 2016.

[4] Yu.A. Tabunschikov, N.V. Shilkin, Aerodinamika vyisotnyih zdaniy. [Online]. Available: https://www.abok.ru/for_spec/articles.php?nid=2662.

[5] K.F. Fokin, Stroitelnaya teplotehnika ograzhdayuschih chastey zdaniy. Pod red. Yu.A. Tabunschikova, V.G. Gagarina. Moskva: AVOK-PRESS, 2006.

[6] D.V. Drozd, Yu.V. Elistratova, A.S. Seminenko, "Vliyanie vetra na mikroklimat v pomeschenii", Sovremennyie naukoemkie tehnologi, no. 8, pp. 37-39, 2013.

[7] V.I. Ledenev, I.V. Matveeva, Fiziko-tehnicheskie osnovyi ekspluatatsii naruzhnyih kirpichnyih sten grazhdanskih zdaniy. Tambov: Izd-vo Tamb. gos. teh. un-ta, 2005.

[8] K.I. Michurina, Vliyanie vetra na teplovyie poteri zhilyih zdaniy $i$ trebovaniya, pred'yavlyaemyie $k$ avtomatizatsii rezhimov teplosnabzheniya. Sbor. Avtomatizatsiya otopitelnyih kotelnyih i teplovyih punktov. JL: Nedra, 1975.

[9] V.S. Falikov, Energosberezhenie v sistemah teplovodosnabzheniya zdaniy: Monografiya. Moskva: GUP «VIMI», 2001.

[10] DBN V.2.2-41:2019. Vysotni budivli. K.: Minrehionbud Ukrainy, 2019.

[11] EN 12831-1:2017. Energy performance of buildings. Method for calculation of the design heat load. Part 1: Space heating load, Module M3-3, 2017.

[12] S.N. Stepanenko, V.G. Voloshin, V.Yu. Kuryishina, "Raschet skorosti vetra v nizhnem 300-metrovom sloe atmosferyi po dannyim meteorologicheskih nablyudeniy s uchetom temperaturnoy stratifikatsii i sherohovatosti poverhnosti", Ukr. hidrometeorol. Zh, no. 17, pp. 23-30, 2016.

[13] V.N. Kupriyanov, Gradostroitelnaya klimatologiya: Uchebnoe posobie. Kazan: Izd-vo Kazanskogo gosudarstvennogo arhitekturno-stroitelnogo universiteta, 2012.

[14] ASHRAE Handbook. Fundamentals. SI Edition, 1997.

[15] DSTU B V.2.6-189:2013. Metody vyboru teploizoliatsiinoho materialu dlia uteplennia budivel. K.: Minrehion Ukrainy, 2014.

[16] DBN V.2.5-28:2018. Pryrodne i shtuchne osvitlennia. K.: Minrehionbud Ukrainy, 2018.

[17] E.V. Vitvitskaya, D.V. Tarasevich, "Changes in lighting standards and their influence on the architecture and energy efficiency of modern residential buildings", Bulletin of Odessa State Academy of Civil Engineering and Architecture, no. 81, pp. 9-17, 2020.

\title{
ВПЛИВ ЗМІНИ ШВИДКОСТІ ВІТРУ НА ЗОВНІШНІЙ ТЕПЛООБМІН БУДІВЕЛЬ
}

\author{
${ }^{1}$ Тарасевич Д. В., к.ф.-м.н., доцент, \\ darya.tarasevych@gmail.com, ORCID: 0000-0002-1153-7669 \\ ${ }^{1}$ Богдан О. В., асистент, \\ ovbogdan@gmail.com, ORCID: 0000-0003-1610-5598 \\ ${ }^{1}$ Одеська державна академія будівниитва та архітектури, \\ вул. Дідріхсона, 4, 65029, Одеса, Україна
}

\begin{abstract}
Анотація. Такі кліматичні фактори, як температура та вологість повітря мають властивість скалярної характеристики, в той час, як сонячна радіація, вітер та опади $\epsilon$ векторними характеристиками. Це необхідно враховувати при виборі архітектурнопланувальних рішень забудови території та архітектурно-конструктивних рішень будівель. У діючих нормативних документах приведені розрахункові кліматичні параметри для проектування огороджувальних конструкцій будівель, розрахунків тепловтрат, регулювання подачі тепла. Практична експлуатація різних будівель та споруд показує, що вибір розрахункових параметрів, у більшості випадків, недостатньо обгрунтований з точки зору вихідних кліматичних даних, і тому вплив зовнішнього середовища на тепловий режим будівлі при розрахунках оцінюється недостатньо, а інколи навіть невірно, що, в свою чергу,
\end{abstract}


впливає на енергоефективність будівель. Одним з таких кліматичних параметрів є вітер: його швидкість та повторюваність впливають на теплообмін конструкції будівлі з навколишнім середовищем, а також на зміну температурного режиму приміщень. Вітровий потік до будівлі створює додатковий тиск на фасад будинку зі сторони напрямку вітру, що призводить не лише до інфільтрації повітря крізь огороджувальні конструкції, а й до збільшення тепловтрат зовнішніми огороджувальними конструкціями.

На основі розрахунково-аналітичного дослідження проаналізована залежність зміни швидкості вітру по висоті та оцінено їі значимість на витрати тепла при опаленні висотних будівель. Зміна швидкості вітру від висоти проаналізована в умовах щільної (міської) і нещільної забудови. Крім того, представлена залежність конвективної складової коефіцієнта тепловіддачі зовнішньої поверхні конструкції від значень швидкості вітру. На основі проведених і представлених розрахунків можна зазначити, що тепловіддача зовнішньої конструкції буде значно більшою для багатоповерхових будинків, ніж для будівель середньої поверховості. Так при зміні швидкості вітру від 5 м/с до 7 м/с конвективна складова коефіцієнта тепловіддачі зовнішньої поверхні зростає на 36 \%. Якщо таку залежність не враховувати при проектуванні, то це може значною мірою вплинути на розрахунок тепловтрат та енергоефективність будівель, особливо коли мова йде про підвищений відсоток скління фасадів.

Проведена оцінка витрат теплоти на опалення навітряного та завітряного фасадів при середніх значеннях температури зовнішнього повітря в опалювальний сезон по Україні. Так, для будівель висотою понад 70 м при розрахунковому значенні швидкості $5 \mathrm{~m} / \mathrm{c}$ витрати тепла збільшуються від 10 \% до 19 \%. Така велика різниця витрат тепла між навітряними та завітряними стінами будівлі вимагають підвищеного теплозахисту стін висотних будівель зі сторони пануючих зимових вітрів. Таким чином, при проектуванні висотних будівель необхідно враховувати зміну швидкості вітру по висоті.

Отримані результати можуть бути корисними як при виборі архітектурно-планувальних рішень, типу матеріалів зовнішніх огороджувальних конструкцій, так і для об'єктивного оцінювання ступеню вітрозахисту окремих будівель та територій.

Ключові слова: швидкість вітру, енергоефективність, коефіцієнт тепловіддачі, тепловий режим, огороджувальні конструкції, навітряний фасад, завітряний фасад.

\title{
ВЛИЯНИЕ ИЗМЕНЕНИЯ СКОРОСТИ ВЕТРА НА ВНЕШНИЙ ТЕПЛООБМЕН ЗДАНИЙ
}

\author{
${ }^{1}$ Тарасевич Д.В., к.ф.-м.н., доцент, \\ darya.tarasevych@gmail.com, ORCID: 0000-0002-1153-7669 \\ ${ }_{1}^{1}$ Богдан О.В., ассистент, \\ ovbogdan@gmail.com, ORCID: 0000-0003-1610-5598 \\ ${ }_{1}^{1}$ Одесская государственная академия строительства и архитектуры, \\ ул. Дидрихсона, 4, 65029, Одесса, Украина
}

\begin{abstract}
Аннотация. Такие климатические факторы, как температура и влажность воздуха имеют свойства скалярных величин, в то время как солнечная радиация, ветер и осадки являются векторными характеристиками. Это необходимо учитывать при выборе архитектурно-планировочных решений территории застройки и архитектурноконструктивных решений зданий. В действующих нормативных документах приведены расчетные климатические параметры для проектирования ограждающих конструкций зданий, расчетов теплопотерь, регулировки подачи тепла. Практическая эксплуатация разных зданий и сооружений показывает, что выбор расчетных параметров, в большинстве случаев, недостаточно обоснован с точки зрения исходных климатических данных и поэтому влияние окружающей среды на тепловой режим здания при расчетах оценивается
\end{abstract}


недостаточно, а иногда даже и неверно, что, в свою очередь, влияет на энергоэффективность здания. Одним из таких климатических параметров является ветер: его скорость и повторяемость влияют на теплообмен конструкции здания с окружающей средой, а также на изменение температурного режима помещений. Ветровой поток к зданию образует дополнительное давление на фасад здания со стороны направления ветра, что приводит не только к инфильтрации воздуха через ограждающие конструкции, но и к увеличению теплопотерь внешними ограждающими конструкциями.

На основе расчетно-аналитического исследования проанализирована зависимость изменения скорости ветра по высоте и оценена ее значимость на потери тепла при отоплении высотных зданий. Изменение скорости ветра по высоте проанализировано в условиях плотной (городской) и неплотной застройки. Кроме того, представлена зависимость конвективной составляющей коэффициента теплоотдачи внешней поверхности конструкции от значений скорости ветра. На основании проведенных и представленных расчетов можно заметить, что теплоотдача внешней конструкции будет значительно больше для высотных зданий, чем для зданий средней этажности. Так при изменении скорости ветра от 5 м/с до 7 м/с конвективная составляющая коэффициента теплоотдачи внешней поверхности возрастает на 36 \%. Если такую зависимость не учитывать при проектировании, это может существенно повлиять на расчет теплопотерь и энергоэффективность зданий, особенно когда речь идет о повышенном проценте остекления фасадов.

Проведенная оценка потерь теплоты на отопление наветренного и заветренного фасадов при средних значениях температуры внешнего воздуха в отопительный сезон по Украине. Так, для зданий высотностью более 70 м при расчетном значении скорости ветра $5 \mathrm{~m} / \mathrm{c}$ потери тепла увеличиваются от $10 \%$ до 19\%. Такая большая разница потерь тепла между наветренными и заветренными стенами здания требуют повышенной теплозащиты со стороны господствующих зимних ветров. Таким образом, при проектировании высотных зданий необходимо учитывать изменения скорости ветра по высоте.

Полученные результаты могут быть полезными как при выборе архитектурнопланировочных решений, типа материалов внешних ограждающих конструкций, так и для объективного оценивания степени ветрозащиты отдельных зданий и территорий.

Ключевые слова: скорость ветра, энергоэффективность, коэффициент теплоотдачи, тепловой режим, ограждающие конструкции, наветренный фасад, заветренный фасад.

Стаття надійшла до редакції 22.03.2021 